\title{
The Development of a Cup Set Design Made from Pottery Based on Local Culture Using the Subahnale Motif of Lombok in Panunjak Village, Central Lombok, West Nusa Tenggara
}

\author{
Anita Armas ${ }^{1}$, Awang Eka Novia Rizali ${ }^{2}$ \\ \{Anita.armas@Trisakti.ac.id ${ }^{1}$, awangenr@trisakti.ac.id ${ }^{2}$ \} \\ Product Design Program, Faculty of Art and Design, Universitas Trisakti, Jakarta ${ }^{1,2}$
}

\begin{abstract}
In Indonesia, the tradition of using pottery as household utensils has been carried out for a long time. Almost all islands in Indonesia have a pottery craft center because the need for the use of pottery is very high as daily necessities or for home decoration. One of the regions that produce pottery in Indonesia is Lombok, West Nusa Tenggara. The people of Lombok are known as people who have high creativity in developing arts and crafts. Penunjak Village is one of the oldest pottery-producing villages on Lombok Island. The majority of the population of Penujak Village, Praya, Central Lombok have a livelihood as pottery craftsmen. Changes in market needs and consumer taste have been faced as a common problem for most of the pottery craftsmen in Penunjak Village. This phenomenon is also a challenge in the field of craft product design. For this reason, research and development of pottery designs are highly needed, aiming at targeting more potential markets and promoting differentiation between the centers of the pottery industry in Indonesia. In this study, the researchers applied the qualitative research method by carrying out a series of actions (action research). This method went through 4 cycles that continued to rotate. Results of this study generated a product by applying the local characters from the Songket motif of Sukarara Village, Central Lombok while maintaining the traditional finishing character. Accordingly, a product that had high differentiation was created and is expected to increase the commercial value of pottery products in Penunjak Village, Praya, Central Lombok.
\end{abstract}

Keywords: Cup; Pottery; Subahnale; Panunjak

\section{Introduction}

Pottery is one of the results of human culture. It is also a very old traditional cultural heritage. According to experts, based on their studies, pottery has been known since the era of farming and used as household utensils.

In Indonesia, the tradition of using pottery as household utensils has been carried out for a long time. Almost all islands in Indonesia have a pottery craft center because the need for the use of pottery is very high as daily necessities or for home decoration. 
One of the regions that produce pottery in Indonesia is Lombok, West Nusa Tenggara. The people of Lombok are known as people who have high creativity in developing arts and crafts. The area of pottery crafts on Lombok Island are divided into 3 major areas, namely Banyu Mulek Village in East Lombok, Masbagik Village in East Lombok, and Panunjak Village in Central Lombok [1].

Penunjak Village is one of the oldest pottery-producing villages on Lombok Island. The majority of the population of Penujak Village, Praya, Central Lombok have a livelihood as pottery craftsmen. These craftsmen are spread over 7 hamlets (Indonesian: dusun), in which each possesses respective specialties and skills. Those hamlets are Andong, Tongkek, Kangi, Mantung, Toro, Terandon, and Telage. Andong is famous for its gentong pottery. Tongkek and Kangi usually produce pottery for candles. Mantung and Toro are famous for their earthenware plate. Meanwhile, Terandon produces malin jugs typical of the Sasak Tribe. Besides, for finishing (final stage), it is concentrated in Telage.

Changes in market needs and consumer taste have been faced as a common problem for most of the pottery craftsmen in Penunjak Village. This phenomenon is also a challenge in the field of craft product design. For this reason, research and development of pottery designs are highly needed, aiming at targeting more potential markets and promoting differentiation between the centers of the pottery industry in Indonesia.

\section{Materials and Methods}

This study applied the model of research and development for creating the cup set design made from pottery in Penunjak Village. In this study, the researchers applied the qualitative research method by carrying out a series of actions (action research) which is a type of research based on data and information obtained during the implementation process.

Action research in the field of design is also often recognized as practitioner research that requires critical self-reflection by the researcher [2]. John W. Creswell has mapped several characteristics of action research, namely a dynamic research process, focusing on practical findings, and having a plan in every action design [3]. Action research can also involve other people to collaborate in the implementation process. The person involved in this study is a pottery craftsman in Penunjak Village, namely Amran from Yulia Pottery. The involvement of pottery craftsmen is also useful to increase the ability and creativity of craftsmen in developing craft designs with more efficient techniques.

The purpose of action research, according to Whitehead \& McNiff, is to generate new knowledge and increase understanding through actions or activities carried out during the research implementation process [4]. In addition, action research also seeks to provide problem-solving through a series of research activities so that the implementation stage will be easier \& faster and the results are more numerous and of high quality.

The cycle in design development is divided into several stages: (1) planning, (2) observation, (3) action, and (4) reflection [5].

The planning stage is the process of describing and analyzing the problems encountered. After the process of analysis, it is continued with the observation stage, namely the process to validate the initial analysis carried out by searching more accurate data and processes. After the data are collected, the next step is action. It is the process of realizing the results of the analysis and observation and producing the expected product. If the product is considered to be less close to solving the problem, the reflection process is carried out, namely evaluating the shortcomings and then repeating the planning process to find out any deficiency in the early stages. 


\section{Results and discussion}

Generating novelty values and differentiation in traditional craft designs is highly needed by craftsmen in responding to various challenges in the era of globalization. Various household appliances made of clay are even starting to be replaced with materials that are more practical, strong, and durable [6].

The business of pottery in Penunjak Village cannot be separated from the increasingly fierce market competition between the centers of the pottery industry throughout Indonesia and even abroad. The differentiation of pottery can be one of the keys to success in breaking away from competition between regions.

The pottery craft from Penunjak Village, Central Lombok is heavily influenced by the design that tends to follow the style of pottery on Java. This results in increasingly fierce competition. In fact, raising the local character possessed by Lombok Island will increase the selling value of the product which can become a unique souvenir from Lombok Island.

The character of the clay in Penunjak Village is very unique because it is quite different from other areas. Its character tends to be lighter, denser, and not too sandy. In making pottery, the craftsmen apply a low-temperature combustion technique using a traditional stove fueled with straw or firewood with a temperature of $400-800^{\circ} \mathrm{C}$ for 4 to 7 hours depending on the size of the pottery being burned. The smaller the size of the pottery is, the longer the burning time will be. What is even more unique for the character of the pottery is the final process (finishing) that does not use chemicals at all but still has natural motifs, such as black spots resulting from spraying liquid from sour fruit when the pottery product is finished baking and is almost cold.

The differentiation of pottery in Penunjak Village, Central Lombok is carried out by taking elements of the Subahnale motif typical of Lombok's songket which is from the center of the songket industry in Sukarara Village, Central Lombok, and by maintaining the traditional finishing process.

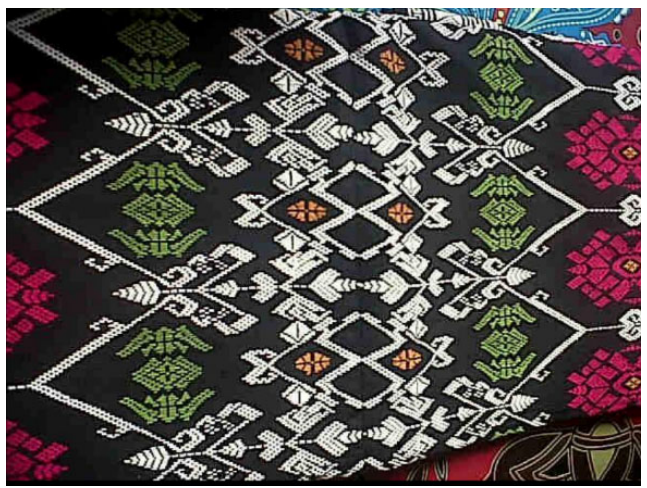

Fig. 1. The Motif of Subahnale Panah Source: Researchers’ Documentation (2021)

In facilitating the production process and product consistency, the slab technique is used. The slab technique is a technique of scraping and drawing using a special clay chisel on a gypsum mold. 


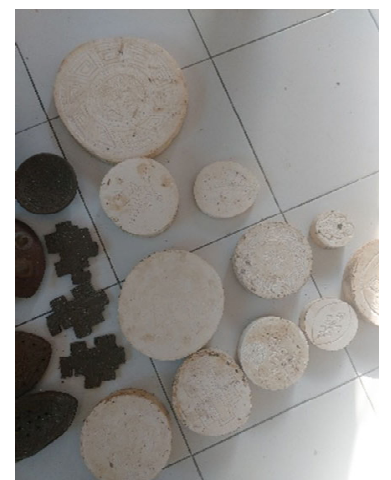

Fig. 2. Gypsum mold with the slab technique Source: Researchers' Documentation (2021)

\subsection{Design development}

Before starting to design, the first thing to determine is the preparation sequence of the design process to make it more effective. As an element of differentiation, the applied local motif is taken from the songket cloth produced by Sukarara Village, Central Lombok. From the many Subahnale motifs, the chosen motif for the development of the first design is Subahnale panah.

After determining the motif that will be applied to the gypsum mold, the next step is the process of simplifying the motif or also known as stylization, making it easy to be applied to pottery.
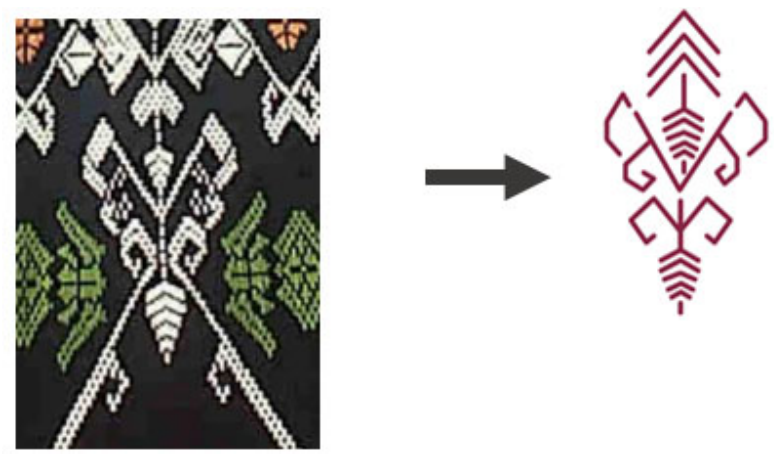

Fig. 3. The process of simplifying the shape in the motif of Subahnale panah Source: Researchers' Documentation (2021)

Furthermore, the next step is making a mold using gypsum material. 


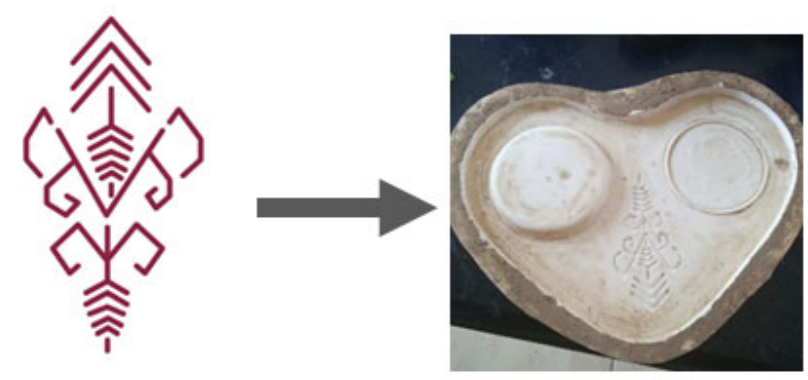

Fig. 4. The motif of Subahnale panah drawn on almost-dry gypsum Source: Researchers' Documentation (2021)

After the mold is ready, the next step is to make the clay plate by kneading the clay to certain flexibility and then flattening it on the gypsum mold until the motif on the mold is printed properly. After that, the next process is the making of a cup set product.

The Subahnale motif on the Sukarara songket can not only be applied to pottery with the slab technique but can also be used as an additional ornament on pottery with other techniques.

By using the Subahnale motif as an ornament on pottery products and maintaining the traditional finishing characteristics (burning with the acid splash technique), the pottery of Panunjak Village, Central Lombok has differentiation from other areas outside Lombok Island.

The acid splash technique is a technique that has been developed by pottery craftsmen in Lombok Island from generation to generation, namely when the pottery product is finished baking and the temperature on the pottery has decreased, the craftsmen spray acid (acid liquid from fruit or chemicals) using a simple sprayer aiming that the pottery has a motif.

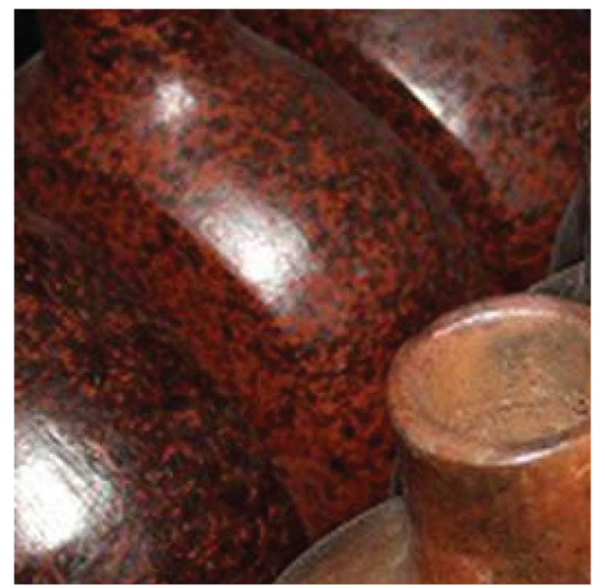

Fig. 5. Finishing using the acid splash technique Source: Craftsman's documentation (2021)

For the design of the cup set, the Subahnale motif is applied to the body of the cups and saucers. 

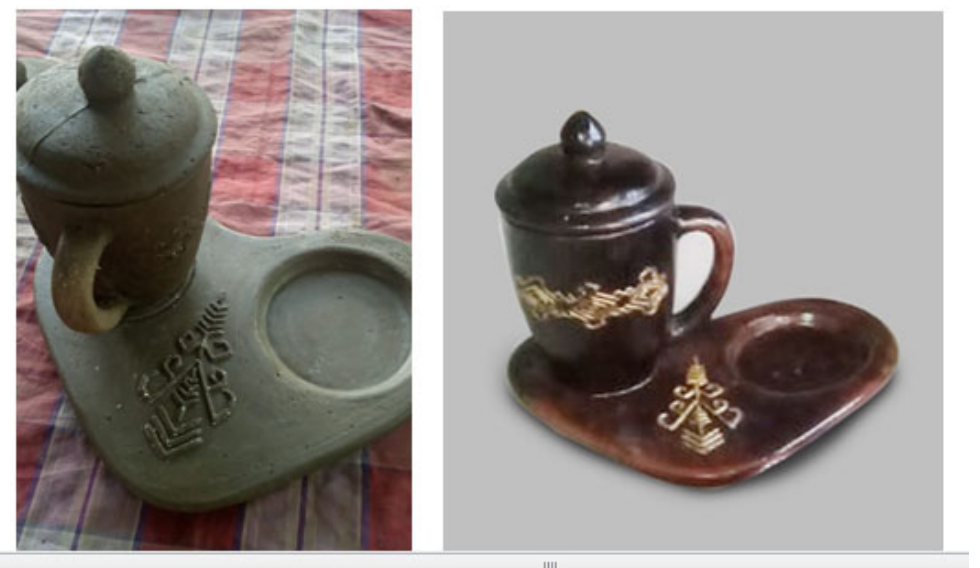

Fig. 5. Generated products with Subahnale ornaments using the slab technique Source: Researchers' Documentation (2021)

\section{Conclusion}

Based on the results of the action research that has been carried out, the design of the cup set product made from pottery at the center of the pottery industry in Panunjak Village, Central Lombok has great potential to be developed and has strong regional differentiation, making it able to increase the commercial value of the product being developed.

A strong local differentiation is found in the cup set ornament inspired by the Subahnale panah motif which is a typical Sasak motif applied to songket cloth, but this time, it is applied to pottery products. In addition, the character of the clay using low-temperature combustion and the final technique that uses acid splashes strengthen the character of pottery which only exists on Lombok Island. The slab printing technique is used to facilitate the consistency of product shape and size when market demand increases.

\section{References}

[1] Mahendra, L. Suartini, dan G. E. H. Koriawan, "Kerajinan Gerabah Desa Penujak Kecamatan Praya Barat Kabupaten Lombok Tengah Provinsi Nusa Tenggara Barat,” $J$. Pendidik. Seni Rupa Undiksha, vol. 4, no. 1, 2014.

[2] J. McNiff, Action research: Principles and practice. New York: Routledge, 2013.

[3] J. W. Creswell, Educational Research:Planning, Conducting and Evaluating Quantitative and Qualitative, 4 ed. Lincoln: University of Nebraska, 2012.

[4] J. Whitehead dan J. McNiff, Action research: Living theory. London: SAGE Publications, Inc., 2006.

[5] K. Oentoro, "Pengembangan desain teko set gerabah kontemporer berbasis budaya lokal di Kabupaten Bojonegoro," Prod. J. Desain Prod. (Pengetahuan dan Peranc. Produk), vol. 3, no. 6, hal. 189-196, 2019.

[6] E. Eskak, I. R. Salma, dan H. Sumarto, "Peningkatan kecerahan dan daya rekat warna pada produk gerabah batik," Prod. J. Desain Prod. (Pengetahuan dan Peranc. Produk), 
vol. 3, no. 1, hal. 1-7, 2017. 